УДК 611.724.013:611.068

DOI: $10.24061 / 1727-0847.17 .2 .2018 .4$

D.B. Stoliar, L.P. Lavriv

Higher State Educational Establishment of Ukraine "Bukovinian State Medical University", Chernivtsi City

\title{
MORPHOMETRIC CHARACTERISTICS OF TEMPOROMANDIBULAR JOINT IN HUMAN DURING THE SECOND TRIMESTER OF INTRAUTERINE DEVELOPMENT
}

\section{МОРФОМЕТРИЧНА ХАРАКТЕРИСТИКА СКРОНЕВО-НИЖНЬОЩЕЛЕПНОГО СУГЛОБА ЛЮДИНИ В ДРУГОМУ ТРИМЕСТРІ ВНУТРІШНЬОУТРОБНОГО РОЗВИТКУ}

Резюме. В статті наведено дані щодо анатомічних особливостей скронево-нижньощелепного суглоба у другому триместрі внутрішньоутробного розвитку, визначених методами препарування, морфометрії та краніометрії. Встановлено, що у плодів 4-6 місяців суглобова ямка має пласку форму. Кісткова речовина суглобової ямки тонка. Спостерігається формування елементів синовіальної оболонки суглобової сумки. У нижньому та верхньому відділах суглобової порожнини визначаються складки та завороти сполучнотканинної пластинки, відбувається вростання капілярів у синовіальну оболонку. Місцями спостерігаються сполучнотканинні перетинки між поверхнями скроневої кістки та суглобового диска, суглобового диска та голівки нижньої щелепи. Макроскопічно суглобовий диск має щільну структуру, розташовується між суглобовими поверхнями, від задньої поверхні суглобового диска до внутрішньої поверхні суглобової сумки визначається сполучнотканинний тяж. Спереду суглобовий диск прикріплюється в ділянці майбутнього суглобового горбика. Правий і лівий скроневонижньощелепні суглоби мають однакові розміри. У динаміці другого триместру внутрішньоутробного розвитку скронево-нижньощелепний суглоб характеризується наявністю пласкої суглобової ямки та відсутністю суглобового горбика. Спостерігається збільшення всіх краніометричних показників, що свідчить про нарощування загальної кісткової маси черепа та збільшення розмірів скроневонижньощелепного суглоба.

Ключові слова: скронево-нижньощелепний суглоб; другий триместр; анатомія; людина.

Modern science has a large number of diagnostic methods: craniological, anatomical, ultrasound, radiological [1]. Currently, the study of human anatomical variability, morphometric characteristics, interrelations of organs, anatomical structures, their parts at all stages of human development is especially topical. Despite the progress and intensive development of dental technology, there are still many unexplained issues regarding the structure of the dentition elements [2,3]. One of its important structures is the temporomandibular joint (TMJ). Anomalies of development or anatomical variants of the TMJ contribute to changes in the shape or development of facial deformities, disrupt swallowing and chewing movements, bite or occlusion $[4,5]$. Among the large number of publications in scientific literature devoted to various aspects of dental anatomy, insufficient attention is paid to anatomy and pathology of TMJ, despite their practical significance.

The objective of the research: to study the anatomical and morphometric peculiarities of TMJ in the second trimester of human intrauterine development.

The object and methods of research. Anatomical peculiarities of TMJ in the second trimester of intrauterine development (4-6-month-old fetuses) were studied on 30 specimens sized 161.0-295.0 $\mathrm{mm}$ of crown-heel length $(\mathrm{CHL})$. The following methods were used in the course of the study: morphometry, craniometry, macro- and microdissection, computed tomography.

Results of the research and their discussion. The glenoid fossa in fetuses aged 4-6 months was found to be flat. The bone substance in the glenoid fossa is thin. There are no pronounced prominences on the basis of the malar eminence of the temporal bone which confirms the absence of the articular tubercle in this period. One can see the development of the elements of the synovial membrane in the articular capsule. In the lower and upper parts of the articular cavity, the folds and ligaments of the connective tissue plate are identified, and the capillaries grow 
into the synovial membrane. In some places there are connective tissue membranes between the surfaces of the temporal bone and the articular disk, the articular disk and the head of mandible. Macroscopically, the articular disk has a dense structure, it is arranged between the articular surfaces, from the back surface (dorsal part) of the articular disk to the inner surface of the articular capsule the taenia of the connective tissue is identified. Anteriorly, the articular disk is attached in the area of the future articular tubercle. The fibers of the lateral wing muscle grow into the taenia of the the connective tissue anteriorly. In the middle part and in the front the lateral wing muscle adjoins to the TMJ, and the parotid gland from the outside and in the upper part. The right and lefts TMJ are of the same size. The morphometric indices of the outer structures of the TMJ in the dynamics of the second trimester are gradually increasing.

4-month-old fetuses are characterized by the flat articular fossa, the articular tubercle is not determined. Synovial membrane is formed in the cavity of the joint. Cartilaginous tissue embraces the outer edge of the condyloid process in the form of strip. The density of the cartilaginous substance increases in the direction towards the surface of the condyloid process, it is difficult to dissect, the cartilage gradually turns into perichondrium and has the appearance of a dense plate. The border between cartilage and osseous tissue is uneven. Lateral pterygoid muscle is attached to the condyloid process from the front. The articular disc is formed by a coarse fibrous connective tissue. The tissue of the articular disc is pierced through by single blood vessels. In certain areas, their number increases, but closer to the attachment of the articular disc to the anterior part of the articular capsule, the number of vessels decreases. Circumference at the level of glabella, parietal tubers and inion (external occipital protuberance) is $132 \pm 7.63 \mathrm{~mm}$, the distance between the parietal tubers equals to $36 \pm 3 \mathrm{~mm}$. The distance between glabella and inion in the sagittal plane is $43.3 \pm 3 \mathrm{~mm}$, the distance between the most remote points of the zygomatic arch is $31.6 \pm 2.08 \mathrm{~mm}$. The distance between the nasion and the gnathion (the lowest point of the midline of the mandible) is 21.6 $\pm 1.5 \mathrm{~mm}$. In 4-month-old fetuses, the distance between the right and left mandibular processes is $28 \pm 4.16 \mathrm{~mm}$, between the right and left gonions $23 \pm 3 \mathrm{~mm}$. The length of the body of the mandible is $15 \pm 1.7 \mathrm{~mm}$, the height of the ramus of the mandible constitutes $6 \pm 0.9 \mathrm{~mm}$. The distance between the right and left mental tubercles is $7 \pm 0.8 \mathrm{~mm}$, between the mandibular process and mental tubercle (the distance of the body of the mandible) $-20 \pm 2 \mathrm{~mm}$. The distance between the gonion and the pogonion is $19 \pm 2 \mathrm{~mm}$, the transverse width of TMJ $-1.62 \pm 0.09 \mathrm{~mm}$.

Beginning from the $5^{\text {th }}$ month, there is a further differentiation of the TMJ structures and the synovial bursa itself, the articular disc and the upper and lower fissure between the articular surfaces are clearly observed, and the size of the fissures is the same (figure). The upper fissure is slightly more medial than the lower one. Articular disc is sutured with the synovial bursa. Further development of the joint occurs in the upper direction. There is an ingrowth of lateral pterygoid muscle into the articular capsule and the articular disc, the articular fossa of the temporal bone remains flat. The distance between the right and left mandibular processes is $40 \pm 3.91 \mathrm{~mm}$, between the right and left gonions $-32 \pm 3 \mathrm{~mm}$. The length of the body of the mandible is $19.2 \pm 1.25 \mathrm{~mm}$, the height of the ramus of the mandible $-8.7 \pm 0.9 \mathrm{~mm}$. The distance between the right and left mental tubercle is $9.5 \pm 0.5 \mathrm{~mm}$, the distance between the mandibular process and the mental tubercle is $25.75 \pm 1.7 \mathrm{~mm}$. The distance between the gonion and the pogonion is $24 \pm 1.6 \mathrm{~mm}$, the transverse width of TMJ constitutes $1.91 \pm 0.07 \mathrm{~mm}$. In 5-month-old fetuses, the circumference measured over glabella, parietal tubers and inion equals to $171.5 \pm 12.6 \mathrm{~mm}$, the distance between the parietal tubers is $45 \pm 4.5 \mathrm{~mm}$, the sagittal distance between glabella and inion is $55.75 \pm 3.86 \mathrm{~mm}$, the distance between the most remote points of the zygomatic arch is $41.1 \pm 3.1 \mathrm{~mm}$, between the nasion and the gnathion $-27.25 \pm 2.21 \mathrm{~mm}$. The TMJ is formed during the $6^{\text {th }}$ month of development. Well-pronounced upper and lower articular fissures are observed. The articular capsule is formed by fibrous tissue. Both capita of the lateral pterygoid muscle and the parotid gland are well distinguished. There is a substitution of cartilaginous tissue of the condyloid process of the mandible by osseous tissue (ossification). The sizes of the lower and upper articular fissures are equal. Articular disc is represented by coarse fibrous cartilaginous tissue. The articular fossa is represented by a thin bone plate. The distance between the right and left mandibular processes is $48.5 \pm 3.87$ $\mathrm{mm}$, between the right and left gonions $-40.2 \pm 1.7$ $\mathrm{mm}$. The length of the body of the mandible is $23.5 \pm 1.2 \mathrm{~mm}$, the height of the ramus of the mandible is $11.2 \pm 0.95 \mathrm{~mm}$. The distance between the right and left mental tubercles is $11.2 \pm 0.95 \mathrm{~mm}$, between the process of the lower jaw and the mental tubercle $33.2 \pm 2.5 \mathrm{~mm}$. The distance between the gonion and the pogonion constitutes $30 \pm 1.4 \mathrm{~mm}$, the transverse width of the TMJ is $2.13 \pm 0.07 \mathrm{~mm}$.

In 6-month-old fetuses, the circumference measured over glabella, parietal tubers and inion equals to $220.5 \pm 18.8 \mathrm{~mm}$, between the parietal tubers it is 


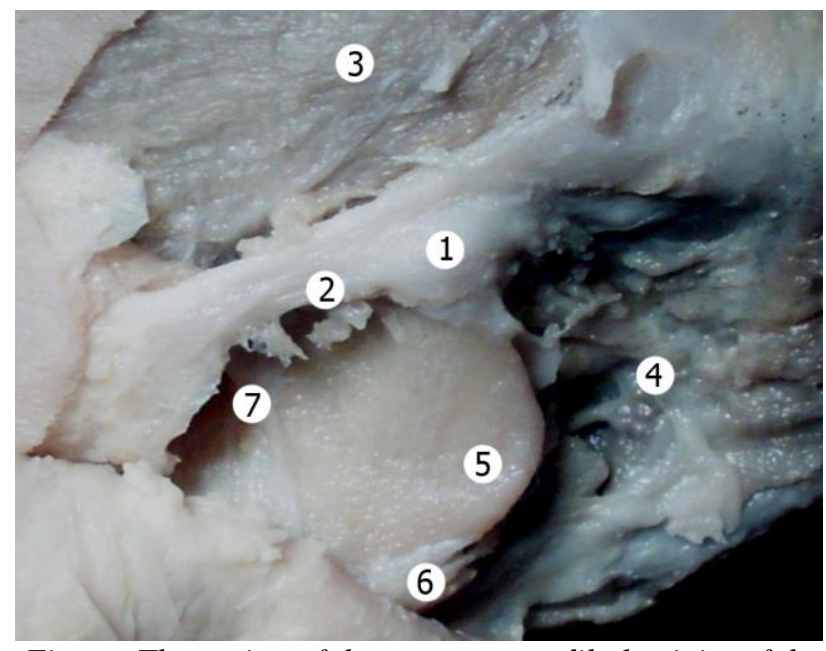

Figure. The region of the temporomandibular joint of the fetus sized $211.0 \mathrm{~mm}$ of crown-heel length. Macroslide. Enhanced x2.6: 1 - temporomandibular joint; 2 -zygomatic bone; 3 -temporal muscle; 4 -parotid gland; 5 mandible; 6 - superficial portion of masseter muscle; 7 profound portion of masseter muscle
$57.5 \pm 5.5 \mathrm{~mm}$. The sagittal distance between glabella and inion is $73 \pm 6.2 \mathrm{~mm}$, the transverse distance between the most remote points of the zygomatic arch is $53 \pm 5 \mathrm{~mm}$, between the nasion and the gnathion it equals to $34.75 \pm 2.2 \mathrm{~mm}$.

Conclusion. Therefore, in the dynamics of the second trimester of intrauterine development, the temporomandibular joint is characterized by the presence of a flat glenoid fossa and the absence of an articular tubercle. An increase in all craniometric indices is observed, indicating an increase in the total bone mass of the skull and an increase in the size of the temporomandibular joint.

Outlooks of the scientific inquiry. The obtained and systematized results of the study can be used in the laboratories for screening morphological material in order to estimate the degree of maturing, for predicting a body's vital capacity as well as diagnosing abnormalities in normal development with suggestions as to their correction.

\section{References}

1. Tuijt M, Koolstra JH, Lobbezoo F, Naeije M. How muscle relaxation and laterotrusion resolve open locks of the temporomandibular joint. Forward dynamic 3D-modeling of the human masticatory system. J Biomech. 2016 Jan 25;49(2):276-83.

2. Ichim I, Swain M, Kieser JA. Mandibular Biomechanics and Development of the human chin. J. Dent Res. $2006 \mathrm{Jul} ; 85(7): 638-42$.

3. Kinniburgh RD, Major PW, Nebbe B, West K, Glover KE. Osseous morphology and spatial relation-ships of the temporomandibular joint: comparisons of normal and anterior disc positions. Angle Or-thod. 2000 Feb;70(1):70-80.

4. Gupta T. Localization of important facial foramina encountered in maxillo-facial surgery. Clin An-at. 2008 Oct;21(7):633-40.

5. Puişoru M, Forna N, Fătu AM, Fătu R, Fătu C. Analysis of mandibular variability in humans of different geographic areas. Ann Anat. 2006 Nov; 188(6):547-54.

\section{МОРФОМЕТРИЧЕСКАЯ ХАРАКТЕРИСТИКА ВИСОЧНО-НИЖНЕЧЕЛЮСТНОГО СУСТАВА ВО ВТОРОМ ТРИМЕСТРЕ ВНУТРИУТРОБНОГО РАЗВИТИЯ}

Резюме. В статье приведены данные анатомических особенностей височно-нижнечелюстного сустава во втором триместре внутриутробного развития, определенных методами препарирования, морфометрии и краниометрии. Установлено, что у плодов 4-6 месяцев суставная ямка имеет плоскую форму. Костное вещество суставной ямки тонкое. Наблюдается формирование элементов синовиальной оболочки суставной сумки. В нижнем и верхнем отделах суставной полости определяются складки и завороты соединительнотканной пластинки, происходит врастание капилляров в синовиальную оболочку. Местами наблюдаются соединительнотканные перегородки между поверхностями височной кости и суставного диска, суставного диска и головки нижней челюсти. Макроскопически суставной диск имеет плотную структуру, располагается между суставными поверхностями, от задней поверхности суставного диска к внутренней поверхности суставной сумки определяется соединительнотканный тяж. Впереди суставной диск прикрепляется в области будущего суставного бугорка. Правый и левый височно-нижнечелюстного сустава имеют одинаковые размеры. В динамике второго триместра внутриутробного развития височнонижнечелюстной сустав характеризуется наличием плоской суставной ямки и отсутствием суставного бугорка. Наблюдается увеличение всех краниометрические показателей, что свидетельствует о наращивании общей костной массы черепа и увеличение размеров височно-нижнечелюстного сустава. Ключевые слова: височно-нижнечелюстной сустав; второй триместр; анатомия; человек. 


\section{MORPHOMETRIC CHARACTERISTICS OF TEMPOROMANDIBULAR JOINT IN HUMAN DURING THE SECOND TRIMESTER OF INTRAUTERINE DEVELOPMENT}

Abstract. The article provides data on the anatomical features of temporomandibular joint in the second trimester of fetal development, certain methods of anatomy, morphometry and craniometry. The glenoid fossa in fetuses aged 4-6 months was found to be flat. The bone substance in the glenoid fossa is thin. One can see the development of the elements of the synovial membrane in the articular capsule. In the lower and upper parts of the articular cavity, the folds and ligaments of the connective tissue plate are identified, and the capillaries grow into the synovial membrane. In some places there are connective tissue membranes between the surfaces of the temporal bone and the articular disk, the articular disk and the head of mandible. Macroscopically, the articular disk has a dense structure, it is arranged between the articular surfaces, from the back surface of the articular disk to the inner surface of the articular capsule the taenia of the connective tissue is identified. Anteriorly, the articular disk is attached in the area of the future articular tubercle. The right and lefts temporomandibular joint are of the same size. In the dynamics of the second trimester of intrauterine development, the temporomandibular joint is characterized by the presence of a flat glenoid fossa and the absence of an articular tubercle. An increase in all craniometric indices is observed, indicating an increase in the total bone mass of the skull and an increase in the size of the temporomandibular joint.

Key words: temporomandibular joint; the second trimester; anatomy; human.

Відомості про авторів:

Столяр Денис Борисович - кандидат медичних наук, асистент кафедри гістології, цитології та ембріології Вищого державного навчального закладу України "Буковинський державний медичний університет";

Лаврів Леся Петрівна - кандидат медичних наук, асистент кафедри анатомії, топографічної анатомії та оперативної хірургії Вищого державного навчального закладу України "Буковинський державний медичний університет".

Information about authors:

Stoliar Denys Borysovych - Candidate of Medical Science, Assistant of the Department of Histology, Cytology and Embryology;

Lavriv Lesia Petrivna - Candidate of Medical Science, senior lecturer of the Department of Anatomy, Topographic Anatomy and Operative Surgery. 